\title{
REDISCOVERY OF THE TERRESTRIAL GREEN ALGA TRENTEPOHLIA AUREA (LINNAEUS) C. MARTIUS (CHLOROPHYTA) IN CROATIA AFTER 130 YEARS
}

\section{Nikola Koletić ${ }^{1}$, Antun Alegro ${ }^{1 *}$, Nina Vuković ${ }^{2}$, Anja Rimac ${ }^{1}$ \& VedRAn ŠEgota ${ }^{2}$}

${ }^{1}$ University of Zagreb, Faculty of Science, Division of Biology, Department of Botany, Marulićev trg 20/II, 10000 Zagreb, Croatia

${ }^{2}$ Herbarium ZA \& ZAHO, Division of Botany, Department of Biology, Faculty of Science, University of Zagreb, Marulićev trg 20/II, 10000 Zagreb, Croatia

Koletić, N., Alegro, A., Vuković, N., Rimac, A. \& Šegota, V.: Rediscovery of the terrestrial green alga Trentepohlia aurea (Linnaeus) C. Martius (Chlorophyta) in Croatia after 130 years. Nat. Croat., Vol. 29, No. 2, 255-265, 2020, Zagreb.

The first record of the terrestrial green alga Trentepohlia aurea for Croatia was made in 1890 in the area of the Krka River, and has remained until this day the only record of this globally widespread species in the country. During studies related to aquatic vegetation, the species was finally rediscovered from the area of Plitvice Lakes, in the Gorski kotar region and near Vukova Gorica village, after 130 years during which no records were made. All recorded populations formed round, woolly, orange-red patches on the surface of rocks and concrete walls, partly forming a community with bryophytes and lichens. In some cases in these mixed communities, Trentepohlia thalli overgrew bryophytes blocking their access to nutrients, water and light. This long period of lack of records of T. aurea in Croatia is mostly a consequence of the discontinuity in research on certain algal groups in Croatia.

Keywords: Čabranka River, Gorski kotar, Kupa River, Plitvice Lakes, terrestrial algae, vegetation relevé

Koletić, N., Alegro, A., Vuković, N., Rimac, A. \& Šegota, V.: Ponovni nalaz kopnene zelene alge Trentepohlia aurea (Linnaeus) C. Martius (Chlorophyta) u Hrvatskoj nakon 130 godina. Nat. Croat., Vol. 29, No. 2, 255-265, 2020, Zagreb.

Prvi nalaz kopnene zelene alge Trentepohlia aurea u Hrvatskoj potječe iz 1890. godine iz područja uz rijeku Krku, i do danas je to za Hrvatsku bio jedini nalaz ove globalno raširene vrste. Tijekom istraživanja vodene vegetacije vrsta je ponovno, nakon 130 godina, pronađena na području Plitvičkih jezera, u Gorskom kotaru, i blizu sela Vukova Gorica. Sve zabilježene populacije činile su okrugle, vunaste, narančasto-crvene nakupine na površini stijena i betonskih zidova, čineći djelomično zajednicu s mahovinama i lišajevima. U nekim slučajevima ovih miješanih zajednica, talusi alge Trentepohlia prerastali su mahovine, blokirajući im pristup nutrijentima, vodi i svjetlu. Dugački period bez nalaza alge T. aurea u Hrvatskoj većinom je posljedica prekida u istraživanjima nekih skupina algi.

Ključne riječi: rijeka Čabranka, Gorski kotar, rijeka Kupa, Plitvička jezera, kopnene alge, vegetacijske snimke

* corresponding author: antun.alegro@biol.pmf.hr 


\section{INTRODUCTION}

Species of terrestrial algae were already known to the early naturalists of the $18^{\text {th }}$ century, who provided the first descriptions of the Trentepohliales (Linnaeus, 1753; Wiggers, 1780). The most distinctive macroscopic trait of Trentepohliales is the formation of golden, brightly orange or red coloured woolly patches, due to the accumulation of carotenoid pigments, mostly $\beta$-carotene. Members of this group can be recognized growing on the surface of various aerial substrates, such as rocks, tree bark, leaves, twigs, fruits, soil, woodwork and concrete, frequently mixed with mosses, cyanobacteria and lichens. They are usually most conspicuous when growing in sun-exposed habitats, where the high irradiance stimulates the production of pigments (RINDi et al., 2018). The Trentepohliales are common in habitats characterized by high atmospheric humidity (Printz, 1939; Chapman, 1984), thus being most diverse and abundant in humid tropical regions, where most of the species occur. Compared to living in an aquatic environment, life for algae in terrestrial habitats involves exposure to harsher conditions, such as nearly complete desiccation, wider and more rapid changes in temperature, stronger insolation and exposure to higher levels of UV radiation (REISSER \& Houben, 2001; GraY et al., 2007; KARSTEN et al., 2007).

Trentepohlia aurea (Linnaeus) C. Martius is composed of uniseriate filaments variously branched and joined to form dense tufts. All species of the genus Trentepohlia reproduce sexually by the production of biflagellate gametes in globular or egg-shaped gametangia. Asexual reproduction involves quadriflagellate zoospores produced in globular or eggshaped sporangia borne on the top of a cell with a characteristically bent-back neck. The main taxonomic characters used for morphological identification of species of Trentepohlia are the shape and size of the cells, branching pattern, presence or absence of hair-like cells and position and habit of gametangia and zoosporangia (RINDi et al., 2018).

Trentepohlia aurea is widespread in temperate and tropical regions (JoHn et al., 2011) and has a worldwide distribution (Guiry \& GuirY, 2020). Authors have recorded the species in numerous European countries, with the first records in Denmark, France, Germany, Great Britain, Italy, Norway, Sweden and Switzerland from 1889, Ireland from 1908, Austria, Bulgaria, Czech Republic, Latvia, Poland, Russia, Slovakia and Spain from 1986, Romania from 2002 and Ukraine from 2011 (ŠKaLOUd et al., 2018).

In the area of today's Croatia, the first and so far the only record of T. aurea is from 1890 by HANSGIRG (1890), who located the species in the area of the Krka River. This is also the only record of any terrestrial alga in Croatia so far. Unfortunately, the record has not been included in any online database or cited in relevant, more recent literature (ŠKALOUD et al., 2018; GuirY \& GuirY, 2020), presumably because in 1890 Croatia was not an independent country but part of the Austro-Hungarian Empire.

The aim of this paper is to present the recent re-discovery of Trentepohlia aurea in Croatia and to emphasize the importance of comprehensive freshwater and terrestrial macroalgal research, followed by the publication of records for the purpose of widening the distributional and ecological knowledge about certain species.

\section{MATERIAL AND METHODS}

Fieldwork was performed in the area of Plitvice Lakes National Park on two occasions and at three sites: on 20 August 2019 in the area of Kozjak Lake and on the right bank of Galovac Lake; and on 25 May 2020 on the left bank of Galovac Lake. The first 
site of Plitvice Lakes was situated at the bottom of the waterfall falling into Kozjak Lake with a northern orientation. In terms of geology, the substratum was dolomite rock inclined at approximately $45^{\circ}$ and covered with a permanently moist layer of tufa. The second site at Plitvice Lakes was on a rocky, northward exposed slope on the right bank of Galovac Lake, with no direct connection to the lake and therefore not influenced by water. The third site in Plitvice Lakes was the left bank of Galovac Lake.

Because the samples at the Kozjak Lake were collected in the spraying zone at the bottom of a waterfall, the physico-chemical properties of the water, namely $\mathrm{pH}$, conductivity, dissolved oxygen and oxygen saturation, were measured using $\mathrm{HACH}$ HQ40D field probes. Average annual temperatures measured at the edges of the waterfalls at the Plitvice Lakes were $11.7^{\circ} \mathrm{C}$, with a minimum of 0 and a maximum of $32^{\circ} \mathrm{C}$ (personal unpublished data).

A site near Vukova Gorica village was visited on 6 January and on 13 June 2020. Localities in the Gorski kotar region between the villages of Zalesina and Dedin were visited on 18 July 2020 and near Čedanj Village on 25 August 2020. Also, during a revision of unsorted herbarium material from the ZA collection in 2020, a sample of T. aurea was found. Collection data for this sample are the following: Croatia, Gorski kotar Region, Čabar Village, canyon of Čabranka River, 45.600607 N, 14.643220 E, 610 m, 22.VII.2011, leg. A. Alegro.

All sites are situated in the Continental Subecoregion of the Dinaric Ecoregion of Croatia (Fig. 1, European Environmental Agency, 2016) within the belt of beech (Fagus sylvatica L.) and beech and fir (Abies alba Mill.) forests (Vukelić, 2012).

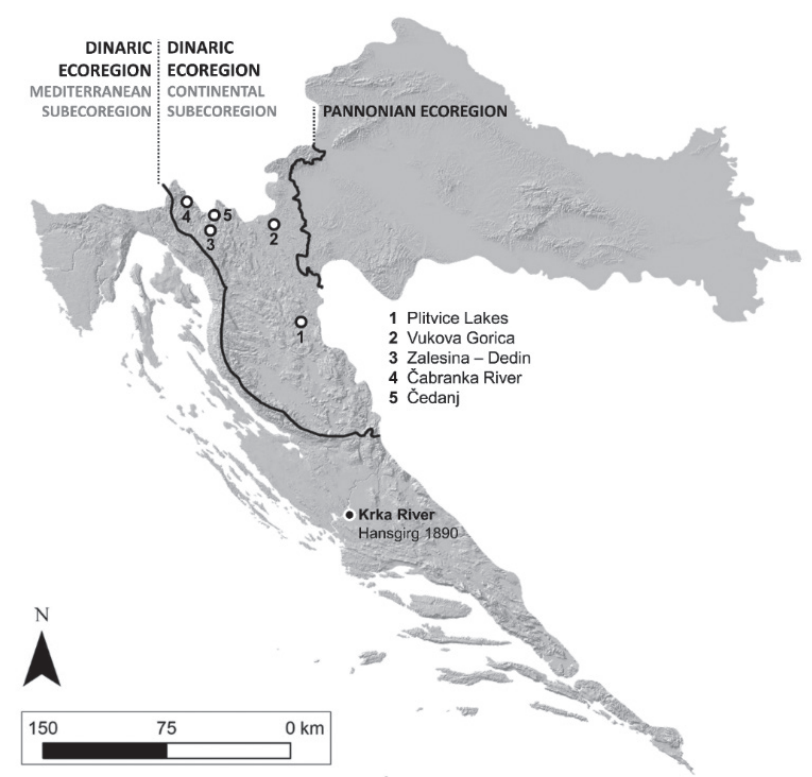

Fig. 1. Map of Croatia showing sites where the occurrence of Trentepohlia aurea is documented: Krka River (1890); Plitvice Lakes (1); Vukova Gorica (2); Zalesina - Dedin in Gorski kotar Region (3); sample from ZA herbarium from Čabranka River (4); and Čedanj in Gorski kotar Region (5). 
In the field, algal material was scraped from the surface with a razor blade. In the laboratory, algal material was identified according to RINDi (2011), using a light microscope. Collected material was deposited in the ZA herbarium (Thiers, 2020). At the sites where the alga was forming communities with bryophyte populations, vegetation relevés on $50 \times 50 \mathrm{~cm}$ plots were made using an expanded Braun-Blanquet nine-degree scale (Braun-Blanquet, 1964; Barkman et al., 1964; DierschKe, 1994). The nomenclature follows AlgaeBase (Guiry \& Guiry, 2020) for algae, Mayrhoffer (2018) for lichens, HodgetTs (2020) for bryophytes and EURO+MED (2020) for vascular plants. The authors of the species names are listed in Tab. 1.

\section{RESULTS}

Populations of terrestrial green alga Trentepohlia aurea were recorded from seven sites in Croatia. All known sites are shown in Fig. 2, while sites with bryophytes, lichens and vascular plants and with vegetation relevés are also listed in Tab. 1 . The thalli on all investigated sites consisted of cylindrical cells, 10-20 $\mu \mathrm{m}$ wide and 20-80 $\mu \mathrm{m}$ long, with mostly pointed apical cells (Figs. 2E, F). The thalii were formed by a prostrate system of creeping filaments that was directly attached to the substratum and from which erect filaments branched profusely. No reproductive structures were observed on the specimens.

Algal populations were recorded on three sites of the Plitvice Lakes; one at Kozjak Lake (Fig. 3A, B) and two on the rocky slopes of Galovac Lake (Fig. 3C). The population of T. aurea consisted of about 15 individual patches, scattered across approximately one square meter of surface. Terrestrial algal, lichen and bryophyte communities were developed on a rocky substrate under the influence of the spraying water from the waterfall. Physico-chemical properties of the water falling into the Kozjak Lake were as follows: conductivity 360-374 $\mu \mathrm{cm}^{-1}, \mathrm{pH}$ 8.36-8.37, oxygen level 8.92-9.30 $\mathrm{mg} \mathrm{L}^{-1}$ and oxygen saturation $110.2-111.0 \%$. Patches of T. aurea were associated with several bryophyte and lichen species characteristic for the vegetation of tufa barriers (Tab. 1). The most abundant bryophytes were Eucladium verticillatum, Hymenostylium recurvirostrum and Didymodon tophaceus (Fig. 2A), while the alga co-occurred with the lichen Collema auriforme (Fig. 2B) both attached directly on the bryophytes (Fig. 2C, D).

On the right bank of Galovac Lake, the population of T. aurea consisted of approximately 50 individual patches occasionally merging and forming larger clusters. The patches were round, woolly and orange-red, between 1 and $3 \mathrm{~cm}$ in diameter, and up to $0.5 \mathrm{~cm}$ thick. On one open, dry, vertical limestone rock, not bearing tufa layer or any vegetation, only a terrestrial algal community was developed. On the left bank of Galovac Lake the finding site was situated out of reach of water, shaded and hidden in a network of tree roots and characterized by high air humidity. The alga was found growing with bryophytes, forming loose carpets of several dozens of square centimetres on small patches of an open, vertical dolomite rock. The most abundant bryophyte was Weissia condensa, partially overgrown by the alga. On the other hand, spots covered by the lichen Verrucaria sp. were not inhabited by the alga (Fig. 3C). Most probably, it was outcompeted by the lichen.

The largest population of T. aurea was recorded at the site near Vukova Gorica village. The alga was found growing on three types of substratum: limestone rocks, a stone wall of limestone origin with the addition of concrete, and concrete walls, situated along the walking path on the edge of a montane beech forest. Orange-red patches 


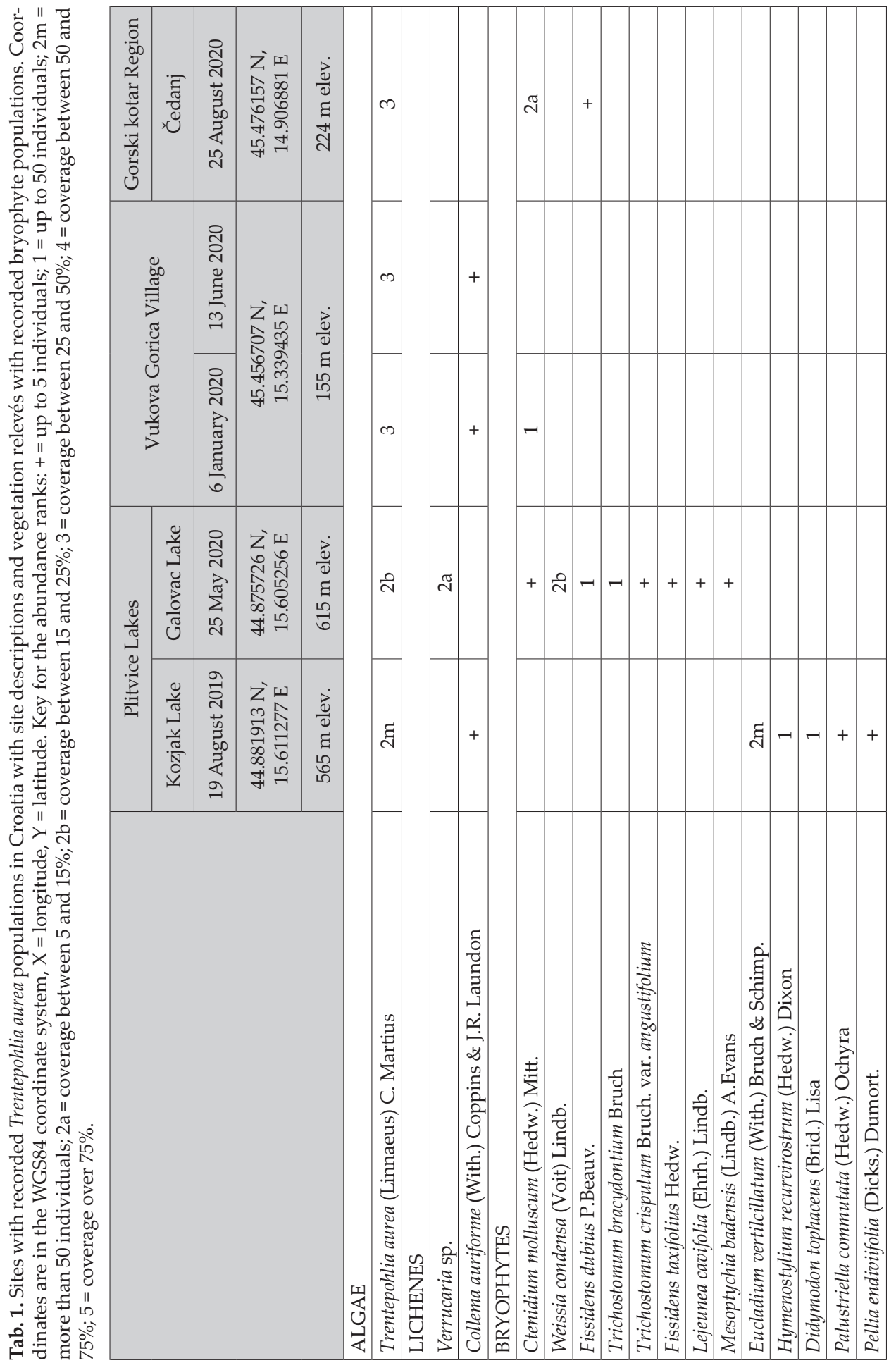




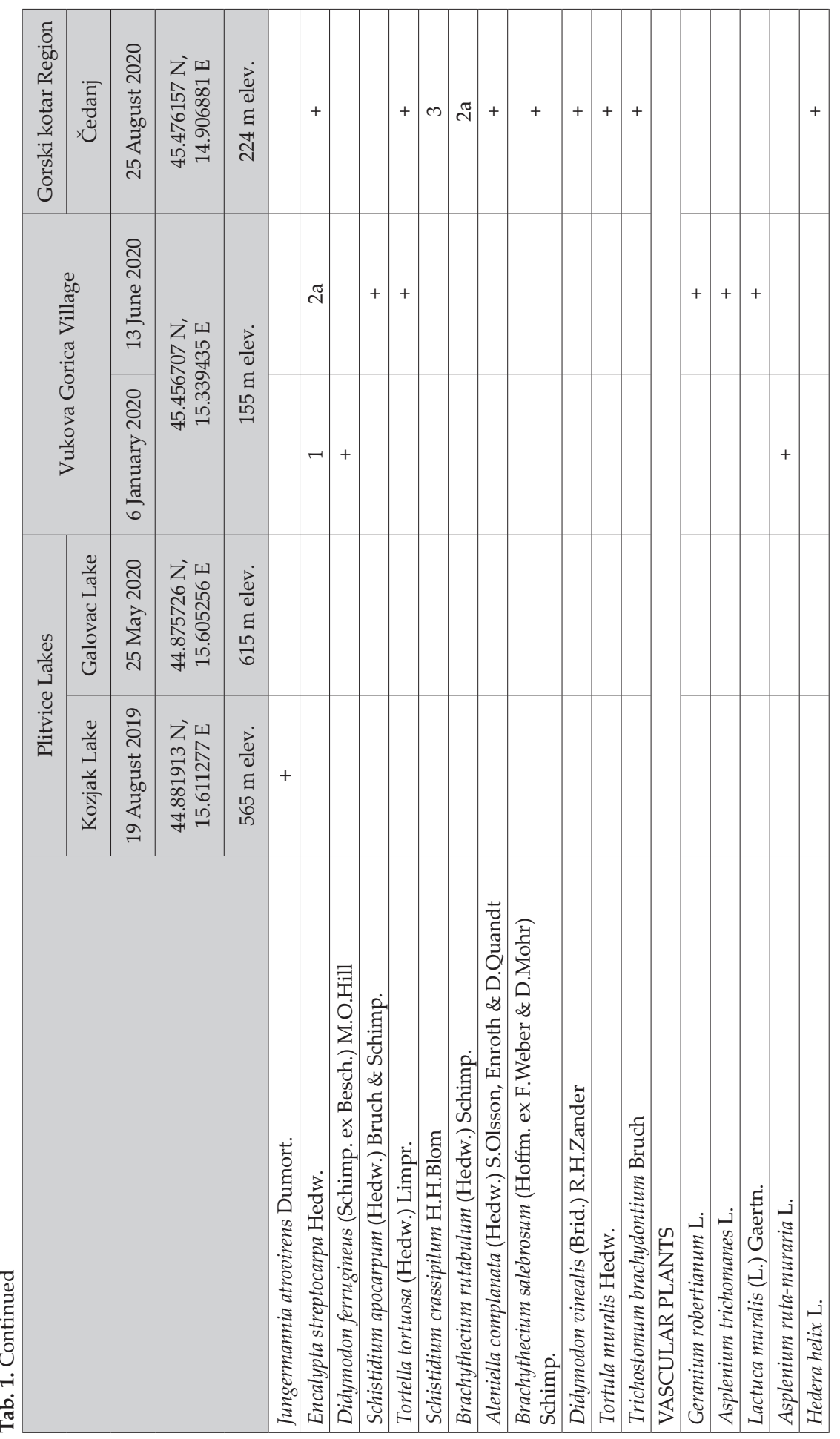



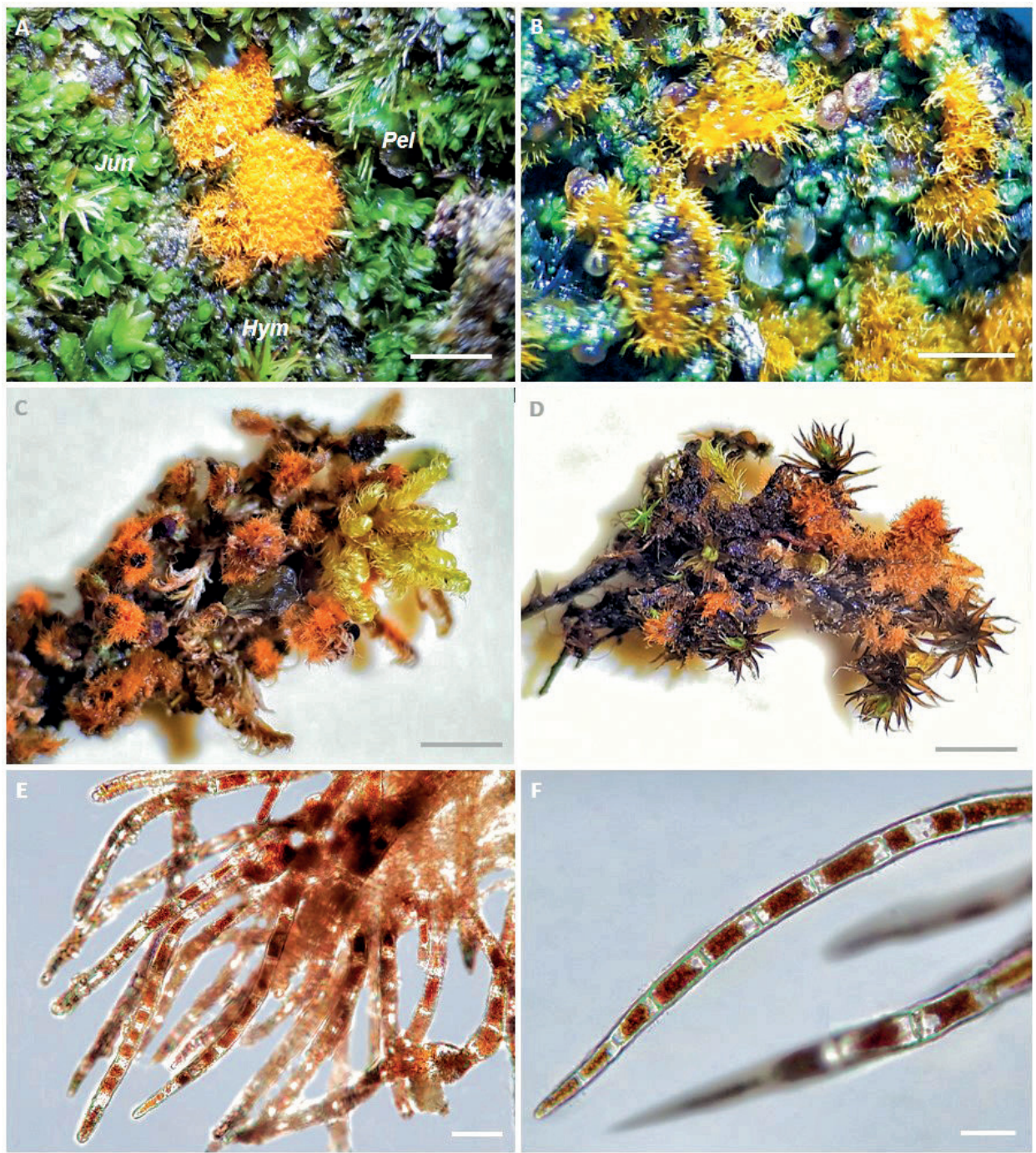

Fig. 2. (A) Patches of Trentepohlia aurea with bryophytes on the site beneath the waterfall on the Kozjak Lake on the Plitvice Lakes, scale $=2 \mathrm{~cm}$ (Hym - Hymenostylium recurvirostrum, Jun - Jungermannia atrovirens, Pel-Pellia endiviifolia); (B) patches of T. aurea from the Kozjak Lake site incorporated with lichen Collema auriforme within bryophytes, scale $=5 \mathrm{~cm}$; (C) T. aurea and C. auriforme covering the bryophyte Ctenidium molluscum, scale $=1 \mathrm{~cm}$; (D) T. aurea and C. auriforme covering bryophyte Hymenostylium recurvirostrum, scale $=1 \mathrm{~cm} ;(\mathbf{E})$ detailed structure of T. aurea thalus showing uniseriate filaments, scale $=100 \mu \mathrm{m} ;(\mathbf{F})$ detailed structure of $T$. aurea filament showing cylindrical cells, scale $=50 \mu \mathrm{m}$.

of alga ranging between 0.5 and $15 \mathrm{~cm}$ in diameter were densely arranged on a surface of approximately several dozen square meters, mostly merged in larger clusters (Fig. 3D, E). The patches inhabiting a stone wall and limestone rocks were found in the close proximity of bryophytes, mainly Ctenidium molluscum and Encalypta streptocarpa, with a few vascular plants scattered in fissures (Tab. 1). Algal patches covered the rock 

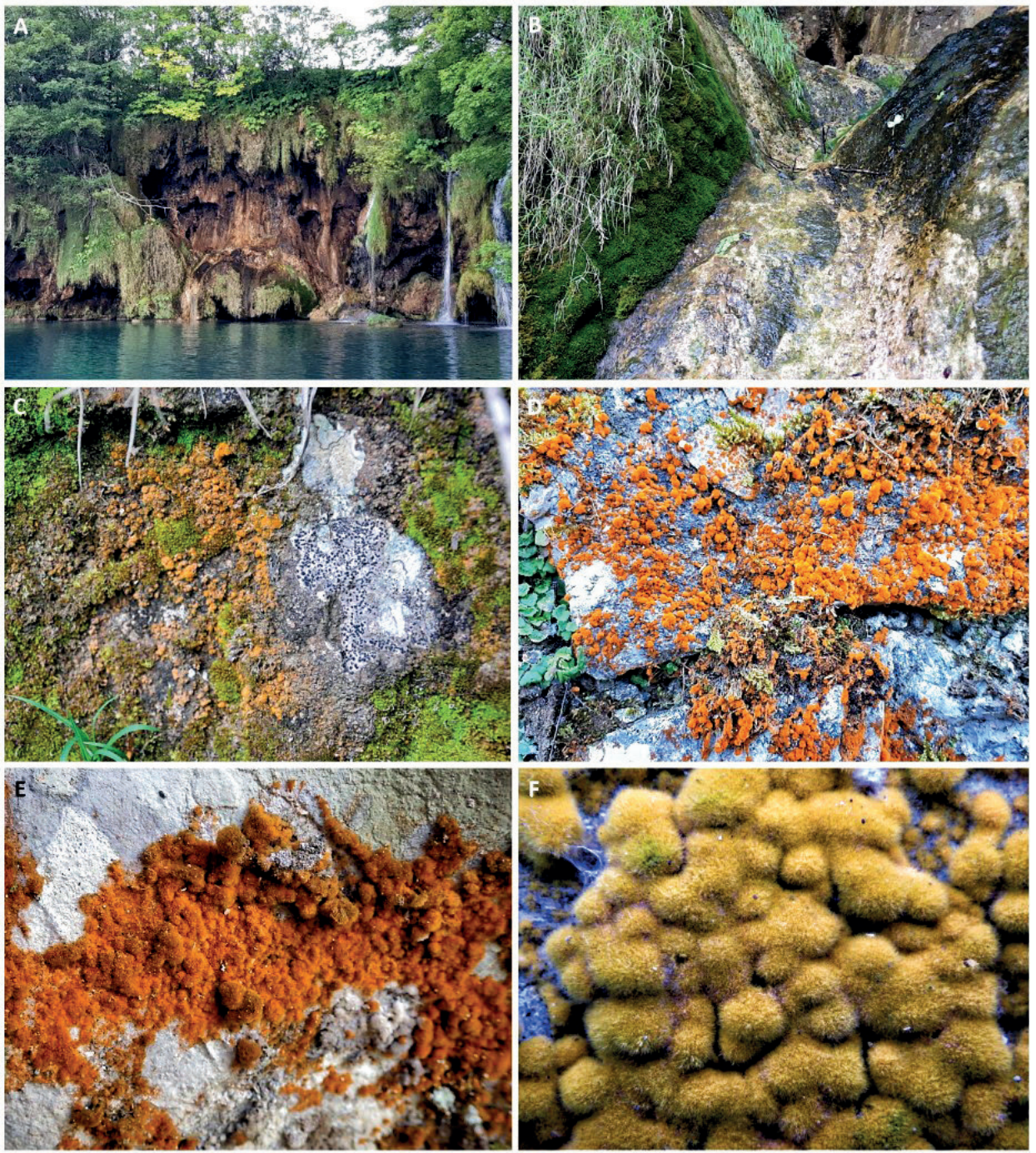

Fig. 3. (A) Tretepohlia aurea beneath the waterfall on the Kozjak Lake on the Plitvice Lakes with (B) detailed photo of the microlocation; (C) site on the left bank of the Galovac Lake; (D) (E) site from Vukova Gorica; (F) site from Čedanj.

surfaces between the bryophytes but were also found abundantly attached directly to the bryophytes, mostly Ctenidium molluscum, with a few thalli on Schistidium apocarpum. Sporadic thalli of the lichen Collema auriforme were also recorded in these populations. On the other hand, there was no bryophyte vegetation at all on concrete walls.

At all three sampling sites in the Gorski kotar region T. aurea was found on artificial walls: a low concrete wall along a walking path in the Čabranka River canyon, a low stone wall along the road connecting the villages Zalesina and Dedin and near the village Čedanj (Fig. 3F). All localities were shaded by beech-fir forest, and the alga was 
found growing in small patches, up to $1 \mathrm{~cm}$ in diameter. The population along the Čabranka canyon was sparse, consisting of small number of patches. On the contrary, an approximately $20 \mathrm{~m}$ long wall was densely covered by algal patches in Dedin, where no bryophyte vegetation was present.

Noteworthily, we observed a tendency of the alga to directly cover the bryophytes in some of the shared sites, e.g. near Vukova Gorica village and at Kozjak and Galovac Lakes (Fig. 2A-D). The samples collected revealed that the parts of bryophytes covered by patches of T. aurea eventually died and served as a base for the growth of the algal thalli, while at the same time the bryophyte spread laterally and outgrew these overlaid areas. This is an example of small-scale interspecific competition, with the alga covering parts of the bryophyte and preventing free access to nutrients, water and light. Also, it is worth mentioning that T. aurea in Croatia occurs in the marginally snowy forest climate, common for the Continental Subecoregion of the Dinaric Ecoregion.

\section{DISCUSSION}

Croatian populations of T. aurea show enivronmental preferences similar to those in other regions where the species occurs (RINDI \& GUIRY, 2002). Even from the small number of described sites, it is evident that the alga has no specific preferences in terms of substratum. It was recorded on natural limestone rocks, tufa formations, stone walls and concrete walls. Nevertheless, high air humidity is common to all the sites, all of them except Dedin being situated very close to waters (lakes and rivers) in the (sub-) montane belt of beech forests. The site in Dedin is, however, characterized by deep tree shade that creates conditions of high atmospheric moisture. The alga was found either in isolated patches or forming a community with bryophytes, but the species composition was variable, with no observable consistency of occurrence of taxa.

The first and only historical Croatian record of T. aurea is mentioned in an article dealing with the flora of Istria and Dalmatia (HANSGIRG, 1890). The alga is mentioned as a part of the flora of the Krka River area. This paper mostly dealt with the vascular flora of the area with a few mentions of algal species found near the river and on the waterfalls of the Krka River. Unfortunately, the paper only presented a species inventory, with no additional information about the species or the exact sites of the records. After this record, a comprehensive study of the algal flora of the Krka River area was performed in 1957 (Golubić, 1957). The author, following the 1890 record, states that he failed to rediscover T. aurea, although he made a detailed study of algal flora of the river and its waterfalls. Such temporal gaps in the algological research in Croatia were, unfortunately, common due to the partly unavailable and inaccessible historical literature and the sporadic freshwater macroalgal research (KolEtić, 2018), which subsequently led to the erroneous publication of some records of macroalgal taxa as first findings (Stanković \& Leitner, 2016; Koletić, 2017).

The long gap between the first record of T. aurea and its rediscovery 130 years later is primarily the result of the lack of research into terrestrial algae and the discontinuity of such research in Croatia. To some extent, this temporal gap can be attributed to almost forgotten historical literature and data, difficult of access and yet valuable, such as that from HANGIRG (1890) and Golubić (1957). Terrestrial algae are indeed a group of organisms that can easily be overlooked or misinterpreted as lichens or fungi. This is the case with the sample of T. aurea from the Čabranka River collected in 2011 which 
was stored in ZA herbarium and left unclassified for nine years. Furthermore, until 2020 T. aurea was not listed for Croatia according to AlgaeBase (GuIRY \& GuIRY, 2020). The findings of this species in Croatia presented support the claim that this species probably has cosmopolitan distribution (JoHn et al., 2011), although due to the lack of targeted research it has remained under the radar for a long time.

\section{CONCLUSION}

The terrestrial green alga T. aurea has been recently recorded in Croatia 130 years after its first discovery in 1890 . This record was partly forgotten, the species not having been included in the relevant databases or literature. In Croatia, T. aurea is present in the area of Plitvice Lakes, Kupa River and Gorski kotar region where it partly forms communities with bryophytes and lichens. According to the literature, T. aurea is a very common alga, and we presume that it is common in Croatia but has been generally unnoticed because it was never an object of investigation.

Received September 30, 2020

\section{REFERENCES}

Barkman, J. J., Doing, H. \& Segal, S., 1964: Kritische Bemerkungen und Vorschläge zur quantitativen Vegetationsanalyse. Acta Botanica Neerlandica 13, 394-419.

Braun-Blanquet, J., 1964: Pflanzensoziologie. Grundzüge der Vegetationskunde, 3. Auflage. Springer Verlag, Wien, New York.

Brooks, F., Rindi, F., Suto, Y., Ohtani, S. \& Green, M., 2015: The Trentepohliales (Ulvophyceae, Chlorophyta): An Unusual Algal Order and its Novel Plant Pathogen, Cephaleuros. Plant Disease 99(6), 740753.

Chapman, R. L., 1984: An assessment of the current state of our knowledge of the Trentepohliaceae, In: Irvine, D. E. G. \& John, D. M. (eds.), Systematics of the Green Algae. Academic Press, London, p. $233-250$.

Croatian Waters, 2015: Draft River Basin Management Plan 2016. - 2021. Hrvatske vode, Zagreb, Croatia.

DierschKe, H., 1994: Pflanzensoziologie. Grundlagen und Methoden. Eugen Ulmer Verlag, Stuttgart.

Euro+Med, 2020: Euro+Med PlantBase - the information resource for Euro-Mediterranean plant diversity. http://www.emplantbase.org (accessed 4 August 2020)

European Environmental Agency, 2016: Biogeographical regions. Available from: https://www.eea. europa.eu/data-and-maps/data/biogeographical-regions-europe-3 (accessed 4 August 2020)

Gray, D. W., Lewis, L. A. \& CARDon, Z. G., 2007: Photosynthetic recovery following desiccation of desert green algae (Chlorophyta) and their aquatic relatives. Plant, Cell and Environment 30, 1240-1255.

Golubić, S., 1957: Vegetacija alga na slapovima rijeke Krke u Dalmaciji (Die Algenvegetation an Wasserfallen des Flusses Krka in Dalmatien). Jugoslavenska akademija znanosti i umjetnosti 312, 207-260.

GuirY, M.D. \& Guiry, G.M., 2020: AlgaeBase. World-wide electronic publication, National University of Ireland, Galway. Available from: http://algaebase.org (accessed: 4 August 2020).

HANsGIRG, A., 1890: Physiologische und algologische Mitteilungen IV. Beiträge zur Kenntnis der Süsswasseralgenflora von Kärnten, Krain, Istrien und Dalmatien. Sitzungsberichte der Böhmischen naturwissenschaftlichen Gesellschaft, Prag.

Hodgetts, N. G., Söderström, L., Blockeel, T. L., Caspari, S., Ignatov, M. S., Konstantinova, N. A., Lockhart, N., Papp, B., Schröck, C., Sim-Sim, M., Bell, D., Bell, N. E., Blom, H. H., BruggemanNannenga, M. A., Brugués, M., Enroth, J., Flatberg, K. I., Garilleti, R., Hedenäs, L., Holyoak, D. T., Hugonnot, V., Kariyawasam, I., Köckinger, H., Kučera, J., Lara, F. \& Porley, R. D., 2020: An annotated checklist of bryophytes of Europe, Macaronesia and Cyprus. Journal of Bryology 42(1), $1-116$. 
John, D., Whitton, B.A. \& BRooк, A.J., 2011: The freshwater algal flora of the British Isles, Second edition. Cambridge Univ Press, Cambridge.

Karsten, U., Lembcke, S. \& Schumann, R., 2007: The effects of ultraviolet radiation on hotosynthetic performance, growth, and sunscreen compounds in aeroterrestrial biofilm algae isolated from building facades. Planta 225, 991-1000.

Koletić, N., Alegro, A., Š Segota, V., Vuković, N., Rimac, A. \& Vilović, T., 2017: New sites of rare coldwater golden algae Hydrurus foetidus (Villars) Trevisan (Ochrophyta: Chrysophyceae) in Croatia. Natura Croatica 26(2), 305-311.

Koletić, N., Alegro, A., Vuković, N., Rimac, A. \& Šegota, V., 2018: Discontinuity in research of macroalgae in Croatian freshwaters - the implications of the gap between historical and recent knowledge, In: ANAČKov G. \& Zorić L. (eds.), Botanica Serbica 42, Suppl. 1, 7BBC Book of abstracts. Institute of Botany and Botanical Garden "Jevremovac", Belgrade, p. 192-192.

Linnaeus, C., 1753: Species plantarum, Vol. II. Impensis Laurentii Salvii, Stockholm.

Mayrhofer, H., Konrad, L.-M., Prettner, M., Seifter, K. \& Bilovitz, P. O., 2018: The lichens of Croata. Phyton 58(1), $1-102$.

MEPPP, 2001: Ministry of Environmental Protection and Physical Planning. Croatia: Karst Conservation Project. Environmental Management Plan.

Papp, B., Alegro, A., ŠEgota, V., Š́ Croatia I. Gorski kotar region (W Croatia). Studia botanica hungarica 44, 193-211.

Printz, H., 1939: Vorarbeiten zu einer Monographie der Trentepohliaceen. Nytt Magasin for Naturvidenskapene 80, 137-210.

Reisser, W. \& Houben, P., 2001: Different strategies of aeroterrestrial algae in reacting to increased levels of UV-B and ozone. Nova Hedwigia 123, 291-296.

RINDI, F., 2007: Diversity, distribution and ecology of green algae and cyanobacteria in urban habitats, In: Sесквасн J. (ed.), Algae and Cyanobacteria in Extreme Environments. Dordrecht, Springer, p. 571-582.

Rind, F., 2011: Order Trentepohliales, In: John D.M. \& Whitton B.A. (eds.), The freshwater algal flora of the British Isles - Second edition. Cambridge University Press, Cambridge, p. 573-577.

Rindi, F. \& GuirY, M. D., 2002: Diversity, life history and ecology of Trentepohlia and Printzina (Trentepohliales, Chlorophyta) in urban habitats in western Ireland. Journal of Phycology 38, 39-54.

Rindi, F., SiKes, J. \& SHAPIRo, L., 2018: The Identity of Trentepohlia Algae (Chlorophyta: Trentepohliales) from Point Lobos State Reserve and the San Francisco Region, California. Madroño 65(2), 89-95.

Stanković, I. \& Leitner, P., 2016: The first record of Hydrurus foetidus (Villars) Trevisan (Ochrophyta: Chrysophyceae) in Croatia with ecological notes. Natura Croatica 25 (2), 223-231.

Škaloud, P., Rindi, F., Boedeker, C. \& Leliaert, F., 2018: Chlorophyta: Ulvophyceae. Freshwater Flora of Central Europe, Vol. 13. Springer Spektrum Berlin. 288 pp.

THIERs, B., 2020: Index Herbariorum. A global directory of public herbaria and associated staff, New York Botanical Garden's Virtual Herbarium. Available from: http://sweetgum.nybg.org/ih/ (accessed: 2 February 2020).

VuKelić, J., 2012: Šumska vegetacija Hrvatske. Šumarski fakultet Sveučilišta u Zagrebu, Državni zavod za zaštitu prirode. Zagreb.

Wiggers, F. H., 1780: Primitiae florae holsaticae. Litteris Mich. Frider. Bartschii Acad., Kiel. 
